\title{
DIFFERENT SOURCES AND LEVELS OF VEGETABLE OILS IN BROILER CHICKEN NUTRITION
}

\author{
V.Ž. Stanaćev ${ }^{1}$, D. Milić ${ }^{1}$, N. Milošević ${ }^{2}$, V.S. Stanaćev ${ }^{2}$, Z. Pavlovski ${ }^{3}$, \\ Z. Škrbić ${ }^{3}$, N. Puvača ${ }^{2}$ \\ ${ }^{1}$ Perutnina Ptuj-Topiko ad., Petefi Brigade 2, 24300 Bačka Topola, Republic of Serbia. \\ ${ }^{2}$ University of Novi Sad, Faculty of Agriculture, Trg Dositeja Obradovića 8, 21000 Novi Sad, \\ Republic of Serbia. \\ ${ }^{3}$ Institute for Animal Husbandry, Auto put 16, P. Box 23, 11080 Beograd, Republic of Serbia. \\ Corresponding author: vidica.stanacev@stocarstvo.edu.rs \\ Original scientific paper
}

\begin{abstract}
The aim of this study was to investigate the effects of soybean, flax and rapeseed oil on productive performance and carcass quality of broilers chickens. At the beginning of the experiment six groups of 40 one day-old chicks, hybrid line Cobb 500 was formed, with five replications. For nutrition two feed mixtures were used. During the first two weeks, in preparation period, chickens were fed with starter mixture, and then with grower mixture until the end of the experiment. Control group was fed with mixture of standard composition and quality based on corn and soybean meal with the addition of $4 \%$ and $8 \%$ soybean oil, while the experimental group included $4 \%$ and $8 \%$ flaxseed oil and $4 \%$ and $8 \%$ rapeseed oil. The experiment lasted 35 days. During the experimental period, chickens were fed and watered ad libitum and microclimatic conditions were constantly monitored. Control of body weight and feed consumption was carried out every seven days. At the end of the experiment 10 chickens from each group were sacrificed for the purpose of testing the carcass quality. Upon completion of the experiment, control group achieved weight of $2122 \mathrm{~g}$ and $2053 \mathrm{~g}$, and the experimental group with flax oil $2164 \mathrm{~g}$ and $2094 \mathrm{~g}$, and the group with rapeseed oil weighs of $2121 \mathrm{~g}$ and $2081 \mathrm{~g}$. Chickens on treatment with $4 \%$ flax oil in the diet achieved significantly higher body mass $(\mathrm{P}<0.05)$ at the end of the experiment compared with the groups who were on treatment with $8 \%$ rapeseed and soybean oil. Soybean oil at a rate of $4 \%$ showed significantly $(\mathrm{P}<0.05)$ increased final body weight compared to body mass of chicks in a group with the addition of $8 \%$ soybean oil. Feed conversion ratio was lowest in the group with the addition of $4 \%$ flax oil and rapeseed oil, and the highest in the group with the addition of $8 \%$ flax oil. The differences found in the carcass quality between the control and experimental groups were not statistically significant $(\mathrm{P}>0.05)$. The largest amount of abdominal fat ( $18.9 \mathrm{~g}$ ) was in the group with the addition of $4 \%$ rapeseed oil and
\end{abstract}


lowest in the group with the addition of $8 \%$ soybean oil $(12.6 \mathrm{~g})$. Based on these results it can be concluded that the addition of $4 \%$ oil showed better productive results, but had no effect on carcass quality of chickens.

Key words: flaxseed oil, rapeseed oil, carcass quality, nutrition, chickens.

\section{Introduction}

High genetic potential of hybrids, which are used for the production of chicken meat, meet the needs of the market at the age of 35 days, and chicken meat with altered structure of fat and polyunsaturated $\omega-3$ fatty acids, substantially reduces cardiovascular diseases. In recent years, special attention has been focused on the effects of nutritional oils and fats, as health is concerned, which is primarily dependent on the presence of single fatty acids, as well as their relationship. The World Health Organization (Whitworth, 2003) recommended that in the human diet, fat should provide $15-30 \%$ of energy, of which saturated fatty acids were represented less than 10\%, polyunsaturated fatty acids (PUFA) of $6-10 \%, \mathrm{n}-6$ PUFA of 5-8\% n-3 PUFA of $1-2 \%$, and less than $1 \%$ trans fatty acids. In poultry nutrition, fats and oils are a source of energy. Their energy value is greater than all the other nutrients present in the mixture, and more than twice compared to the carbohydrates. Mixtures usually contain fats or oils from different sources, which contribute to variations in the chemical composition and nutritive value (Wiseman et al., 1996; Leeson and Summers, 2005). In recent years, researchers have studied the impact of type and quantity of oil to increase the intensity, the efficiency of feed utilization, carcass quality and meat quality of chickens. In this way, tests are performed by Nobakht et al. (2011) and found that $4 \%$ of pure soybean, rapeseed and sunflower oil, and their mixtures in the diets for broiler chickens have significant impact on production performance, carcass quality and content of vitamin $\mathrm{E}$ in the breast meat. The same authors found that the best feed conversion ratio (1.83) is in the group with a mixture of $2 \%$ of the oil from rapeseed and soybean with the lowest relative share of the gizzard $(2.52 \%)$, while the highest amount of vitamin $\mathrm{E}$ in white meat $(22.05 \mathrm{mg} / \mathrm{kg})$ was recorded in the group with a mixture of all three oils. Lopez-Ferrer et al. (2011) concluded that 2 and $4 \%$ flaxseed oil in diets for broilers, with the addition of fat to $8 \%$ affects the fatty acid composition of tissue, while the production parameters showed minor differences between treatments. The yield carcass weight and meat quality between the groups were not significant. However, the results of Bartos et al. (2004) showed a negative effect of addition of $6 \%$ of linseed oil to the broiler diet mixture when it comes to carcass quality. The introduction of 3\% rapeseed oil in the diet of broiler chickens showed a significant increase in body weight compared to the control group, while the difference in mass of the liver, white and red meat were not significant 
(Shahyar et al., 2011). Addition of 4\% flax oil in the diet of broiler chickens has resulted in a higher concentration of fat in the liver, compared with chickens on treatment with $4 \%$ rapeseed oil. Rapeseed oil in mixtures for broiler chickens leads to a reduction in lipid content in the edible parts of the carcass, especially saturated fatty acids in white muscle and liver, as well as monounsaturated fatty acids of red and white meat, liver, and gizzard (Zanini et al., 2006). DeWitt et al. (2009) showed that the introduction of $6 \%$ sunflower and fish oil leads to improved feed conversion of broiler chickens, which is consistent with previous research of $E l$ Yamany et al. (2008) in terms of production performance of Japanese quail. The research of Stanacev et al. (2012), which aimed to investigate the effect of different vegetable oils in the diet of broiler chickens, concluded that the use of 4 and $8 \%$ flaxseed oil does not exhibit significant differences in production parameters and carcass quality. Previous research of Stanaćev et al. (2011) came to the conclusion that the inclusion of extruded rapeseed in quantities of 10,15 and $20 \%$ in chicken diets, significantly affect the final body weight compared with the control group. Also same authors (Stanaćev et al., 2011), noted significant changes when it comes to the fatty acid composition of lipids in chicken meat under the influence of feeding treatment, where was recorded the reduction of linoleic acid by $20 \%$ and increase in the content of linoleic acid by $50 \%$. Given the above, the aim of this study was to examine the production parameters and carcass quality of broilers 35 days old, fed with different amounts of soybean, flaxseed and rapeseed oils.

\section{Material and Methods}

Trials were conducted under production conditions on the experimental estate "Pustara" in Temerin, on the floor system. At the beginning of the experiment six groups of 40 one day-old chicks hybrid line Cobb 500 were formed, with five replications. For nutrition two feed mixtures were used. During the first two weeks of chickens preparation period, starter mixture containing $21 \%$ protein were used, while then grower mixture with $20 \%$ protein was used until the end of the experiment. Control group was fed with mixture of standard composition and quality based on corn and soybean meal with the addition of $4 \%$ and $8 \%$ soybean oil, while the experimental group included $4 \%$ and $8 \%$ flaxseed oil and $4 \%$ and $8 \%$ rapeseed oil (Table 1). The experiment lasted 35 days. During the experimental period, chickens were fed and watered ad libitum and microclimatic conditions constantly monitored. Control of body weight and feed consumption was carried out every seven days. At the end of the experiment (on $35^{\text {th }}$ day), from each group 10 birds ( 5 males and 5 females), with mean body weight were sacrificed for the purpose of testing the carcass quality. Operation such as bleeding, scalding, plucking, evisceration and cooling were performed. Classically processed carcasses was measured and cut to the basic anatomical parts and measured (Regulations: 
Fig. Gazette of SFRY, No.1/81 and 51/88). Evaluations were conducted on the basis of yield and weight of certain body parts. For proper interpretation of the results, appropriate statistical methods of ANOVA and Tacky post-hoc test of software package STATISTICA 12 were used.

Table 1. Experimental plan with chickens

\begin{tabular}{|l|c|c|c|c|c|c|}
\hline $\begin{array}{l}\text { Group and } \\
\text { Treatment }\end{array}$ & Control, I (T5) & Control, II (T6) & III (T1) & IV (T2) & V (T3) & VI (T4) \\
\hline Oil source & Soybean & Soybean & Flaxseed & Flaxseed & Rapeseed & Rapeseed \\
\hline In grower & $4 \%$ & $8 \%$ & $4 \%$ & $8 \%$ & $4 \%$ & $8 \%$ \\
\hline
\end{tabular}

\section{Results and Discussion}

Based on the obtained results it can be concluded that this set of experiments demonstrated significant differences $(\mathrm{P}<0.05)$ between the different types and amounts of vegetable oils. During the preparation period chicks had a uniform body weight. Upon completion of the experiment at 35 day, small rise in depression in group on treatment with $4 \%$ rapeseed oil is noted, compared to the control group, while the III, IV and VI groups were superior in body weight. Highest body weight of $2164 \mathrm{~g}$ achieved chickens of group III on treatment with $4 \%$ flax oil, which is $1.97 \%$ higher than in the control group with the same amount of soybean oil, and the lowest weight was chicken group V with $4 \%$ rapeseed oil with $2121 \mathrm{~g}$ or $0.05 \%$ less than in the control group (Table 2). During the third week, significant differences $(\mathrm{P}<0.05)$ between groups II and IV are visible, while in the fourth week highly significant differences $(\mathrm{P}<0.01)$ is appeared between the control group with $8 \%$ soybean oil and experimental groups III, IV, V and VI, as well as between groups I and VI, until the fifth week when body mass of chickens had almost leveled for the same amount of oil. Statistically significant difference was maintained between the II and VI group at 8\% soybean and rapeseed oil.

Table 2. Body weight of 35 day old chickens, g

\begin{tabular}{|l|c|c|c|c|c|c|}
\hline \multirow{2}{*}{$\begin{array}{l}\text { Chicken } \\
\text { age } \\
\text { (weeks) }\end{array}$} & \multicolumn{7}{|c|}{ Group, treatment and amount of oil } \\
\cline { 2 - 7 } & Control, I (T5) & Control, II (T6) & III (T1) & IV (T2) & V (T3) & VI (T4) \\
\cline { 2 - 7 } & $4 \%$ - Soybean & $8 \%$-Soybean & $4 \%$-Flaxseed & $8 \%$-Flaxseed & $\begin{array}{c}4 \% \text { - } \\
\text { Rapeseed }\end{array}$ & $\begin{array}{c}8 \% \text { - } \\
\text { Rapeseed }\end{array}$ \\
\hline IW & 42 & 42 & 42 & 42 & 42 & 42 \\
\hline 1 & 185 & 185 & 183 & 190 & 187 & 190 \\
\hline Index, \% & 100 & $469 \pm 38,1$ & $468 \pm 28,3$ & $468 \pm 33,2$ & $469 \pm 42,5$ & $469 \pm 33,6$ \\
\hline 3 & $986 \pm 57,2$ & $967^{\mathrm{b}} \pm 58,3$ & $989 \pm 52,8$ & $997^{\mathrm{B}} \pm 54,7$ & $995 \pm 64,5$ & $977 \pm 55,4$ \\
\hline 4 & $1457^{\mathrm{bD}} \pm 155,3$ & $1422^{\mathrm{ABCD}_{1}} \pm 134,1$ & $1523^{\mathrm{A}} \pm 127,3$ & $1532^{\mathrm{B}} \pm 125,6$ & $1515^{\mathrm{C}} \pm 154,1$ & $1575^{\mathrm{D}} \pm 90,8$ \\
\hline 5 & $2122^{\mathrm{E}} \pm 231,5$ & $2053^{\mathrm{a}} \pm 212,0$ & $2164^{\mathrm{A}} \pm 260,2$ & $2094 \pm 231,5$ & $2121 \pm 255,1$ & $2081^{\mathrm{a}} \pm 223,7$ \\
\hline Index, \% & 100 & 100 & 101,97 & 101,99 & 99,95 & 101,36 \\
\hline
\end{tabular}


Same big letters in the same row = highly significant $(\mathrm{P}<0.01)$; same big and small letters in the same row $=$ significant $(\mathrm{P}<0.05)$; same small letters in the same row $=$ not significant $(\mathrm{P}>0.05)$

The use of different types and amount of oil was found to have different efficiency of feed utilization (Table 3). In the preparatory period steady feed consumption per kilogram of gain was recorded (1.30 to 1.36). However, in experimental period from thread to fifth weeks of age, it can be seen that most efficiently exploiting feed was in III and V group with the addition of $4 \%$ flax and rapeseed oil (1.60), while the highest conversion of 1.68 and $1.63 \mathrm{~kg} / \mathrm{kg}$ gain is recorded in the IV and VI group who were on treatment with $8 \%$ of flax and rapeseed oil.

Table 3. Feed conversion, $\mathrm{kg} / \mathrm{kg}$

\begin{tabular}{|l|c|c|c|c|c|c|}
\hline \multirow{3}{*}{ Period } & \multicolumn{7}{|c|}{ Group, treatment and amount of oil } \\
\cline { 2 - 7 } & $\begin{array}{c}\text { Control, I } \\
\text { (T5) }\end{array}$ & $\begin{array}{c}\text { Control, II } \\
(\mathrm{T} 6)\end{array}$ & III (T1) & IV (T2) & V (T3) & VI (T4) \\
\cline { 2 - 7 } & $\begin{array}{c}4 \%- \\
\text { Soybean }\end{array}$ & $\begin{array}{c}8 \%- \\
\text { Soybean }\end{array}$ & $\begin{array}{c}4 \%- \\
\text { Flaxseed }\end{array}$ & $\begin{array}{c}8 \% \text { - }^{-} \\
\text {Flaxseed }\end{array}$ & $\begin{array}{c}4 \% \text { - }^{-} \\
\text {Rapeseed }\end{array}$ & $\begin{array}{c}8 \% \%^{-} \\
\text {Rapeseed }\end{array}$ \\
\hline 1 & $1,13 \pm 0,06$ & $1,16 \pm 0,06$ & $1,14 \pm 0,06$ & $1,12 \pm 0,11$ & $1,14 \pm 0,04$ & $1,08 \pm 0,03$ \\
\hline 2 & $1,35 \pm 0,04$ & $1,34 \pm 0,05$ & $1,30 \pm 0,03$ & $1,35 \pm 0,09$ & $1,36 \pm 0,06$ & $1,33 \pm 0,02$ \\
\hline Index, \% & 100 & 100 & 96,29 & 100,74 & 100,74 & 99,25 \\
\hline 3 & $1,38 \pm 0,14$ & $1,36 \pm 0,14$ & $1,39 \pm 0,22$ & $1,42 \pm 0,03$ & $1,41 \pm 0,03$ & $1,41 \pm 0,03$ \\
\hline 4 & $1,49 \pm 0,03$ & $1,48 \pm 0,04$ & $1,41 \pm 0,06$ & $1,50 \pm 0,02$ & $1,47 \pm 0,03$ & $1,50 \pm 0,09$ \\
\hline 5 & $1,62 \pm 0,03$ & $1,61 \pm 0,04$ & $1,60 \pm 0,04$ & $1,68 \pm 0,04$ & $1,60 \pm 0,02$ & $1,63 \pm 0,05$ \\
\hline Index, \% & 100 & 100 & 98,76 & 104,34 & 98,76 & 101,24 \\
\hline
\end{tabular}

Average values of carcass weight, dressing percentage and weight of certain body parts, as well as their relative share of the weight of dressed carcass, shown in Table 4, indicate that there is very little difference in all tested parameters and that the effect of feeding treatment on carcass yield was not statistically significant $(\mathrm{P}>0.05)$. The relative contributions of valuable body parts by weight of dressed carcass shows that breast as one of the most valuable parts, had the largest representation in the carcass, which ranged from 29.57 to $32.41 \%$, followed by back 18.11 to $19.82 \%$, then the thigh from 12.69 to $13.65 \%$ and leg with 10.79 to $11.43 \%$. The wings have the lowest representation with 9.15 to $9.58 \%$. The amount of abdominal fat was relatively small, ranging between 12.6 and $18.9 \mathrm{~g}$. Since abdominal fat is a good indicator of total fat content, it can be concluded that the carcasses were not greasy. 
Table 4. Chicken carcass quality

\begin{tabular}{|c|c|c|c|c|c|c|}
\hline $\begin{array}{l}\text { Group and } \\
\text { treatment }\end{array}$ & $\begin{array}{l}\text { Control, I } \\
\text { (T5) }\end{array}$ & $\begin{array}{l}\text { Control, II } \\
\text { (T6) }\end{array}$ & III (T1) & IV (T2) & $\mathrm{V}(\mathrm{T} 3)$ & VI (T4) \\
\hline $\begin{array}{l}\text { Source and } \\
\text { amount of } \\
\text { oil }\end{array}$ & $\begin{array}{c}4 \%- \\
\text { Soybean }\end{array}$ & $\begin{array}{c}8 \%- \\
\text { Soybean }\end{array}$ & $\begin{array}{c}4 \%- \\
\text { Flaxseed }\end{array}$ & $\begin{array}{c}8 \%- \\
\text { Flaxseed }\end{array}$ & $\begin{array}{c}4 \%- \\
\text { Rapeseed }\end{array}$ & $\begin{array}{c}8 \%- \\
\text { Rapeseed }\end{array}$ \\
\hline \multicolumn{7}{|c|}{ Chicken mass, $\mathrm{g}$} \\
\hline $\begin{array}{l}\text { Before } \\
\text { slaughter, g }\end{array}$ & 2157 & 2075 & 2170 & 2118 & 2097 & 2121 \\
\hline $\begin{array}{l}\text { Carcass } \\
\text { weight, g } \\
\text { (CP) }\end{array}$ & 1755 & 1706 & 1827 & 1756 & 1792 & 1781 \\
\hline $\begin{array}{l}\text { Dressing, } \\
\% \text { (CP) }\end{array}$ & 81,34 & 82,23 & 84,17 & 82,91 & 85,43 & 83,98 \\
\hline $\begin{array}{l}\text { Carcass } \\
\text { weight, } \quad \mathrm{g} \\
\text { (RG) }\end{array}$ & 1476,0 & 1426,1 & 1532,3 & 1474,4 & 1503,0 & 1488,6 \\
\hline $\begin{array}{l}\text { Dressing, } \\
\% \text { (RG) }\end{array}$ & 68,42 & 68,72 & 70,61 & 69,61 & 71,67 & 70,18 \\
\hline \multicolumn{7}{|c|}{ More valuable body part mass, $g$} \\
\hline Wings & $160,6 \pm 10,8$ & $163,3 \pm 20,7$ & $169,0 \pm 14,3$ & $165,8 \pm 13,2$ & $168,4 \pm 24,3$ & $170,4 \pm 13,9$ \\
\hline Thigh & $189,6 \pm 17,9$ & $189,1 \pm 17,3$ & $201,5 \pm 22,8$ & $195,5 \pm 22,4$ & $194,9 \pm 25,5$ & $204,1 \pm 23,2$ \\
\hline Drumstick & $239,2 \pm 17,3$ & $222,2 \pm 23,9$ & $232,9 \pm 51,9$ & $231,3 \pm 24,0$ & $231,5 \pm 36,1$ & $234,4 \pm 25,9$ \\
\hline Breast & $566,1 \pm 73,7$ & $528,8 \pm 74,3$ & $591,6 \pm 46,9$ & $562,7 \pm 57,5$ & $578,2 \pm 77,1$ & $527,0 \pm 45,7$ \\
\hline Back & $320,5 \pm 17,1$ & $322,7 \pm 29,7$ & $337,3 \pm 59,5$ & $319,1 \pm 47,9$ & $330,0 \pm 43,3$ & $352,7 \pm 30,3$ \\
\hline Total & 1476,0 & 1426,1 & 1532,3 & 1474,4 & 1503,0 & 1488,6 \\
\hline Index, \% & 100 & 100 & 103,81 & 103,38 & 101,82 & 104,38 \\
\hline \multicolumn{7}{|c|}{ Less valuable body part mass, $g$} \\
\hline $\begin{array}{l}\text { Abdominal } \\
\text { fat }\end{array}$ & $18,6 \pm 6,1$ & $12,6 \pm 4,0$ & $17,4 \pm 4,7$ & $15,4 \pm 5,3$ & $18,9 \pm 5,7$ & $17,5 \pm 5,3$ \\
\hline Liver & $36,3 \pm 4,3$ & $36,1 \pm 4,1$ & $35,8 \pm 4,9$ & $37,1 \pm 4,6$ & $37,0 \pm 5,5$ & $37,6 \pm 8,0$ \\
\hline Heart & $10,0 \pm 1,7$ & $10,2 \pm 2,0$ & $10,4 \pm 1,7$ & $10,5 \pm 1,2$ & $10,1 \pm 1,1$ & $9,9 \pm 1,1$ \\
\hline Gizzard & $29,3 \pm 5,2$ & $27,2 \pm 4,8$ & $30,1 \pm 4,2$ & $27,9 \pm 5,5$ & $27,4 \pm 3,8$ & $29,2 \pm 6,8$ \\
\hline Head & $44,5 \pm 4,6$ & $48,8 \pm 5,0$ & $50,3 \pm 4,9$ & $46,1 \pm 4,8$ & $49,2 \pm 5,4$ & $46,8 \pm 6,3$ \\
\hline Neck & $75,2 \pm 13,2$ & $76,6 \pm 11,6$ & $77,3 \pm 9,7$ & $75,1 \pm 8,1$ & $78,5 \pm 13,0$ & $77,9 \pm 12,4$ \\
\hline Legs & $64,8 \pm 9,4$ & $68,6 \pm 7,8$ & $73,0 \pm 13,5$ & $69,7 \pm 11,4$ & $67,5 \pm 11,2$ & $73,8 \pm 14,1$ \\
\hline Total & 278,7 & 280,2 & 294,4 & 281,9 & 288,7 & 292,8 \\
\hline Index, \% & 100 & 100 & 105,60 & 100,60 & 103,55 & 104,50 \\
\hline \multicolumn{7}{|c|}{ Relative share of more valuable body parts, $\%$} \\
\hline Wings & 9,15 & 9,42 & 9,26 & 9,44 & 9,39 & 9,58 \\
\hline Thigh & 10,79 & 11,08 & 11,03 & 11,11 & 10,86 & 11,43 \\
\hline Drumstick & 13,65 & 12,99 & 12,69 & 13,16 & 12,88 & 13,13 \\
\hline Breast & 32,25 & 30,98 & 32,41 & 32,09 & 32,29 & 29,57 \\
\hline Back & 18,27 & 18,93 & 18,47 & 18,11 & 18,39 & 19,82 \\
\hline
\end{tabular}




\section{Conclusion}

Based on these results it can be concluded that the chickens on treatment with 4\% flax oil in the diet achieved highest body mass at the end of the experiment compared with the groups who were on treatment with $8 \%$ of vegetable oil. The differences were statistically significant $(\mathrm{P}<0.05)$. Highest body weight $(2164 \mathrm{~g})$ was in chickens of group III with $4 \%$ flax oil, and the smallest in chickens of $\mathrm{V}$ group $(2121 \mathrm{~g}$ ) with $4 \%$ rapeseed oil in diet. The largest amount of abdominal fat $(18.9 \mathrm{~g})$ was in the fifth group with the addition of $4 \%$ rapeseed oil and lowest in the control group (II) with the addition of $8 \%$ soybean oil $(12.6 \mathrm{~g})$. Based on these results it can be concluded that the addition of $4 \%$ oil showed better productive results, but had no effect on chicken carcass quality.

\section{Acknowledgement}

The paper is part of the projects TR 31033 and III 46012, funded by the Ministry of Science and Technology of the Republic of Serbia.

\section{Različiti izvori i nivoi ulja u ishrani brojlera}

V.Ž. Stanaćev, D. Milić, N. Milošević, V. Stanaćev, Z. Pavlovski, Z. Škrbić, N. Puvača

\section{Rezime}

Cilj ovog rada je bio da se ispita efekat ulja soje, lana i uljane repice na proizvodne parametre i kvalitet trupa brojlera. Na početku ogleda formirano je šest grupa sa po 40 jednodnevnih pilića linijskog hibrida Cobb 500, u pet ponavljanja. $\mathrm{Za}$ ishranu su korišćene dve smeše. Tokom prve dve nedelje pripremnog perioda, za ishranu pilića je korišćena starter, a potom grover smeša do kraja eksperimenta. Kontrolna grupa je hranjena smešom standardnog sastava i kvaliteta na bazi sojine sačme i kukuruza sa dodatkom $4 \%$ i $8 \%$ ulja soje, dok je u eksperimentalnim grupama bilo uključeno $4 \%$ i $8 \%$ lanenog ulja, odnosno $4 \%$ i $8 \%$ ulja repice. Ogled je trajao 35 dana. U toku eksperimentalnog perioda piliću su hranjeni i napajani po volji, a mikroklimatski uslovi redovno kontrolisani. Kontrola telesne mase i utroška hrane je vršena svakih sedam dana. Na kraju eksperimenta žrtvovano je po 10 pilića iz svake grupe za potrebe ispitivanja kvaliteta trupa. Po završetku eksperimentalnog perioda, kontrolna grupa je ostvarila masu od $2122 \mathrm{~g}$ i $2053 \mathrm{~g}$, a ogledne grupe sa uljem lana 2164g i 2094g, dok su grupe sa repičinim uljem 
ostvarile masu od $2121 \mathrm{~g}$ i $2081 \mathrm{~g}$. Pilići na tretmanu sa $4 \%$ ulja lana u ishrani ostvarili su statistički značajno veću telesnu masu $(\mathrm{P}<0,05)$ na kraju eksperimenta u poređenju sa grupama koje su bile na tretmanu sa $8 \%$ ulja repice i soje. Ulje soje u količini od $4 \%$ je takođe statistički značajno $(\mathrm{P}<0,05)$ uticalo na povećanje završne telesne mase u poređenju sa telesnom masom pilića u grupi sa dodatkom $8 \%$ sojinog ulja. Konverzija hrane je bila najniža u grupi sa dodatkom $4 \%$ ulja lana i uljane repice, a najviša u grupi sa dodatkom $8 \%$ ulja lana. Utvrđene razlike u kvalitetu trupa između kontrolne i oglednih grupa nisu bile statistički značajne $(\mathrm{P}>0,05)$. Najveća količina abdominalne masti $(18,9 \mathrm{~g})$ je u grupi sa dodatkom $4 \%$ ulja repice, a najmanja u grupi sa dodatkom $8 \%$ ulja soje $(12,6 \mathrm{~g})$. Na osnovu dobijenih rezultata može se zaključiti da je dodatak $4 \%$ ulja ispoljio bolje prozvodne rezulate, ali nije uticao na kvalitet trupa pilića.

\section{References}

BARTOS A., PAL L., BANYAI A., HORVATH P., WAGNER L., DUBLECZ K. (2004): Effect of different oil (fat) supplemented diets on the performance, carcass quality and fatty acid composition of tissues of broiler chicks. Allattenyesztes es Takarmanyozas, 53(1), 63-78.

DEWITT J.C., COPELAND C.B., STRYNAR M.J., LUEBKE R.W. (2009): Perfluorooctanoic acid-induced immunomodulation in adult female chicks. Environ Health Perspect, 116, 645-650.

EL YAMANY A.T., HEWIDA M., EL ALLAWY H., LAILA D., ABD ELSAMEE A., EL-GHAMRY A. (2008): Evaluation of using different levels and sources of oil in growing Japanese quail diets. American-Eurasian Journal of Agricultural \& Environmental Science, 3(4), 577-582.

LEESON S., SUMMERS J.D. (2005): Ingredient evaluation and diet formulation: Flaxseed. Commercial Poultry Nutrition. 3rd ed. University Books, Guelph, Ontario, Canada, 44-46.

LOPEZ-FERRER S., BAUCELLS M.D., BARROETA A.C., GALOBRAT J., GRASHORN M.A. (2011): n-3 enrichment of chicken meat. 2. Use of precusors of long-chain polyunsaturated fatty acids: linseed oil. Poultry Science, 80, 753-761.

NOBAKHT A., SAFAMEHR A., SOZANY S., GALANDARI I., TAGHAVI E., GHABOLI I. (2011): Comparison of effects of using different levels of animal and vegetable fats and their blends on performance of laying hens. Brazilian Journal of Poultry Science Research, 1, 1433-1437.

SHAHRYAR H.A., NOBAR R.S., LAK A., LOTFI A. (2011): Effect of dietary supplemented canola oil and poultry fat on the performance and carcass characterizes of broiler chickens. Current Research Journal of Biological Sciences, 3(4), 388-392. 
STANAĆEV V., KOVČIN S., STANAĆEV V., PUCAREVIĆ M., PUVAČA N. (2011): Extruded canola seed in improving chicken fattening and fatty acid composition. Kuwait Journal of science and Engineering, 38(1A), 71-80.

STANAĆEV V., MILOŠEVIĆ N., STANAĆEV V., PUVAČA N., MILIĆ D., BJEDOV S., PLAVŠA N., BEUKOVIĆ D., LJUBOJEVIĆ D. (2012): Sources and effects of different levels of oil on production performance and broiler carcass quality. Proceedings of $6^{\text {th }}$ Central European Congress on Food - CEFood, Novi sad, 23-26 May, 1625-1629.

WHITWORTH J.A. (2003): 2003 World Health Organization (WHO)/International Society of Hypertension (ISH) statement on management of hypertension. Journal of Hypertension, 21(11), 1983-1992.

WISEMAN S.A., MATHOT J.N.N.J., DE FOUW N.J., TIJBURG L.B.M. (1996): Dietary non-tocopherol antioxidants present in extra virgin olive oil increase the resistance of low-density lipoproteins to oxidation in rabbits. Atherosclerosis, 120, 15-23.

ZANINI S.F., COLNAGO G.L., PESSOTTI B.M.S., BASTOS M.R., CASAGRANDE F.P., LIMA V.R. (2006): Body fat of broiler chickens fed diets with two fat sources and conjugated linoleic acid. International Journal of Poultry Science, 5(3), 241-246. 